\title{
Meta
}

Journal des traducteurs

Translators' Journal

\section{Household Words}

\section{Peter J. Wexler}

Volume 39, numéro 4, décembre 1994

Hommage à Bernard Quemada : termes et textes

URI : https://id.erudit.org/iderudit/004595ar

DOI : https://doi.org/10.7202/004595ar

Aller au sommaire du numéro

Éditeur(s)

Les Presses de l'Université de Montréal

ISSN

0026-0452 (imprimé)

1492-1421 (numérique)

Découvrir la revue

Citer cet article

Wexler, P. J. (1994). Household Words. Meta, 39(4), 757-764.

https://doi.org/10.7202/004595ar

\section{Résumé de l'article}

Un dépouillement de l'hebdomadaire Household Words dirigé par Charles Dickens nous permet de reculer la datation d'une cinquantaine de mots que l' Oxford English Dictionary date du XX ${ }^{\mathrm{e}}$ siècle. Il s'agit essentiellement de mots techniques du début des années 1850, qui sont présentés en contexte, avec, en regard, la datation fournie par l' $O E D$. 


\title{
HOUSEHOLD WORDS
}

Peter J. WeXLER

Colchester, Essex, England

\begin{abstract}
Résumé
Un dépouillement de l'hebdomadaire Household Words dirigé par Charles Dickens nous permet de reculer la datation d' une cinquantaine de mots que l'Oxford English Dictionary date du $X X^{e}$ siècle. Il s'agit essentiellement de mots techniques du début des années 1850 , qui sont présentés en contexte, avec, en regard, la datation fournie par l'OED.
\end{abstract}

\begin{abstract}
A reading of Charles Dicken's weekly Household Words reveals at least 50 antedating of words for which the Oxford English Dictionary gives a 20th century dating. These words, from the early 1850's, are mostly of a technical nature. They are presented in context, together with their OED dating.
\end{abstract}

From Household Words, the weekly 'conducted' by Charles Dickens, the $O E D$ has about 200 quotations. A re-reading - not of course claiming exhaustivity - has found about 4000 more, mostly omissions and antedatings, with some corrections, substantial postdatings, and gap-fillers (where a chronological sequence of examples has a gap of a century or more).

This may be an extreme case, but high ratios of 'gleanings' to original harvest are not uncommon. The exceptional case, as far as my own reading in the 18th and 19th centuries goes, is rather the text which will not well repay re-prospecting.

Nor, on reflection, is this so surprizing, given the ambiguities inherent in the original ambition of including 'every word' - a target which must soon have come to seem as unsatisfactory by its apparent inclusiveness as by its apparent exclusiveness, in most if not all likely interpretations of 'word'. It would be interesting to trace the process by which the editorial staff reached some degree of consensus on the criteria for inclusion; but this, important though it is, is only a small part of the problem. For it is evidently desirable that the criteria for submission to the editors should be less stringent than the criteria for eventual publication by the editors. For example, an item may well seem less bizarre in the collective experience than in that of any one contributor; or an item may gain sufficient interest by its place in a series. But contributors so disciplined that they never try to second-guess the editors must be very rare, even after long practice. The many volunteer readers of the first generation, and even some of their successors, could hardly be expected to understand how hospitable the criteria for admission were to become, when even the editorial staff "were embarking on an uncharted sea". Wide disproportions between original harvest and later gleanings indicate the difficulty of reaching even a rough consensus on what should count as an item worth submitting (even supposing agreement on what should count as an item worth publishing). No amount of editorial expertise can make up for material which a reader has overlooked or excluded as uninteresting.

Thus it is that this one title can provide over 50 antedatings of words for which $O E D$ gives a 20th-century date of first occurrence; that is, words antedated by between 50 and 126 years. A selection of other technological antedatings and omissions follows, with authors' names provided by Anne Lohrli's Table of contents (Toronto 1973). It

Meta, XXXIX, 4, 1994 
shows that Dickens and his 'young men' were tirelessly interested in the details - and the terminology - of an extraordinarily wide range of crafts both new and traditional, humble and large-scale, from paper-making to stage-machinery, from haberdashery to cannon-founding. In this we cannot doubt that they reflected the interests of their readership. The 1850s were exciting times, lexically speaking. Something of this excitement was surely a factor in the launch of the $O E D$ itself in the unprecedentedly hospitable criteria the dictionary came to adopt, and perhaps also in the choice of name for Dickens' journal.

An 1854 passage from an article by Lowe illustrates how far fascination with technical terminology can go. Here and in the following lists I add, in brackets, the date of the earliest or latest example in $O E D$, for antedatings or postdatings respectively. A single asterisk marks items without an entry in $O E D$ double asterisk entries for which $O E D$ gives no example:

We read of Petershams [1873], friezes, mohairs, and unnumbered cloakings [1874], of vestings, called baratheas [1862], Valentias, *velvettas, *sealetts and gambroons; ${ }^{*}$ Coventry plushes, and *brocardelts. Calicoes, and cotton fabrics, in all their countless and unaccountable nomenclature; - domestics [1823], *Croydons, *Wigans, *Derries, cantoons [1688], hair cords [1866] and smooth soft lappings [1771] not inappropriately called *bishop's lawn. Then, of dyed goods, came Silesias, *Casbans, *constitutions, and permanents [1882], threads, cottons, *window-lines, and tassels; *sampler canvas, foundation muslins [1858], *wirepiping and ${ }^{*}$ dress-fasteners. Who shall unveil the particulars of such mysterious articles as stiffening or *petticoat cord? What are *vause fringes, and wherein do they differ from *toilet fringes? What distinguishes the round head country pins from the heavy London ditto? Or what are *Lillekins? Shall we penetrate the mysteries of *trouser-straps, or busks, or gaiters? Here are Shakespeare collars [1907], for ladies. And in needles; how shall we distinguish the super*drilled-eyed sharps from the groundowns [1862]? Then, as to hooks and eyes; what are the patent ${ }^{*}$ swan bills? (abridged)

advertising media [1927] 1851 S. BLANCHARD \& W. H. WILLS 585 The act-drops [1884] of more than one of the minor Parisian theatres yield a handsome revenue by being converted into expansive advertising media.

air-brick ** 1853 G. DODD 287 Ventilation is ensured by the use of air-bricks.

air engine [1873] $1852 \mathrm{H}$. MORLEY 567 These little engines are air-engines.

all-sorts [1931] $1851 \mathrm{R}$. H. HORNE $173 \mathrm{Keeps}$ a shop in the sweet business. Means that he sells rock, and toffee, and bull's eyes, and all-sorts, and such-like.

anchorsmith [1703] 1853 G. DODD 275 A busy group of anchorsmiths, copper merchants, mast and block makers, shipping butchers, and ship-chandlers.

axle-box [1871] 1852 G. A. SALA 205 A porter hurried by thrusting grease into the hot greedy maw of the axle-box.

bacon-curer [1869] 1852 G. DODD 473 The sides of Irish bacon .. are consigned to baconcurers and provision-merchants.

balance-box $1850 \mathrm{~W}$. H. WILLS 52 The engine, pulls up the balance-box of the pump, which then comes down upon the water-trap.

ballast-bag [1890] 1852 R. H. HORNE 22 A lower division.. has a hole in it to admit water, with an air-hole above; by means of which water-weight at the lower end, the buoy is ballasted. This lower division.. is called the ballast-bag.

bandoline [1861] 1851 W. B. JERROLD 66 Hence dumb-bells, shoulder-boards, gymnastic exercises,.. kalydors, odontos, Columbian balms, bandolines, and a thousand other ingenious devices. 
barrel screw 1853 W. B. JERROLD \& W. H. WILLS 447 Distinguishing worm screws from barrel screws.

beer-engine [1823] 1852 G. A. SALA 29 May 253 There is a beer-engine and there are beer-drinkers [1664].

beer-heading **1852 H. MORLEY 17 July 424 The inky taste perceptible in spurious 'Guiness's' . . is caused by a mixture called beer-heading, which produces a mockery of the fine cauliflower head, and is composed of salt, alum, and green vitriol.

beer-machine $* * 1851 \mathrm{R}$. H. HORNE Christmas $5 \mathrm{He}$ has had a new beer-machine for his bar.

beet-grower ** $1855 \mathrm{E}$. SAUL 482 The beet-growers must make the best of it they can.

black-ware $1854 \mathrm{G}$. DODD 188 The English potters made very little else than common *coarse-ware; but . . Wedgwood . . introduced . . Queen's ware . .; then, basalt, or black-ware, . .; then, *bamboo biscuit.

blast engine [1875] 1852 G. DODD 97 The wasted heat is believed to be enough to . work the blast engines for three furnaces.

blast-wall $1852 \mathrm{R}$. H. HORNE 461 A great black slanting structure, which you are told is a 'blast-wall'.

blowing-cylinder ** 1851 P. LEIGH 350 An aperture connected with a blowing-cylinder [in a furnace].

bobbiner 1853 J. LOWE 348 The Spinners' and Self-actors' Committee sees to the spinners, the minders, the piecers, and the bobbiners.

boiler-master $1852 \mathrm{~J}$. HANNAY 140 There are . . six engineers, and a boiler-master.

bonding warehouse ** 1852 G. A. SALA 29 Dock upon dock, quays after quays, "quay berths,' loading and unloading sheds, long lines of bonding warehouses.

boot-hook [1808] 1854 S. SIDNEY 250 To pull on the boots . required a long struggle, with aid of **boot-powder and boot-hooks.

bowstring girder ** $1852 \mathrm{G}$. DODD 591 In the bow-string girder .. there has been found an efficient principle for many recently-built bridges.

breaking-point [1899] 1852 R. H. HORNE 27 Mar. He tries each chain up to sustaining a weight of thirty tons - eighty tons being known as the fair breaking point.

brine-boiling $* 1855 \mathrm{G}$. DODD 563 Brine-boiling and salt-making, is hot steaming work.

brush-wheel [1875] $1852 \mathrm{G}$. DODD 332 The sheets of carton are passed over a brushwheel.

burster 1 [1862] 1854 SHARP 340 Among the contents of the various boxes attached to each gun-carriage - near-box, off-box, middle-box, and so on - are fuse-boxes, . . bursters, quick-match and fuse-bags.

cane-bottomed [1877] 1852 G. A. SALA 338 A face .. all holes and knots like a canebottomed chair.

capsule v. [1859] 1855 E. S. DIXON 364 A Cognac inventor . . has patented, his clever machine for capsuling the [corked bottle].

car-driver ** 1853 G. A. SALA 22 A car-driver was summonsed . . for stumping a brother whip, i.e. inveigling a fare away from him.

card-hand, -maker [1732], -making [1751], -printer 1852 G. DODD 332 One of the card-hands . . can cut up . . twenty thousand cards in a day. - 331 Why should card-makers fret themselves? - 329 The poetry of card-making. - 330 Watching the card-printers at work.

carquèse Glassm. 1851 W. H. WILLS 436 The bed or 'sole' of this carquèse is heated. 
centre-punch [1879] 1851 DICKENS 105 Two smiths .. were sorely solicitous about 'a centre-punch' which one of them had in his pocket.

chaff-cutter [1807] 1854 S. SIDNEY \& W. H. WILLS 117 Neal, the mechanic, stepped in with a chaff-cutter.

cheek-plate $1852 \mathrm{H}$. MARTINEAU 17 Here are the cheek-plates . . and the gorgets.

china-stone [1875] $1854 \mathrm{G}$. DODD 189 The hardest and finest pieces [of growan] . . are quarried under the name of china-stone.

coal-sack 2 [1870] $1851 \mathrm{H}$. MORLEY 72 The southern cross, the Magellanic clouds, the 'coal-sack' attract our notice.

coke-maker 1852 G. DODD 99 Coke-makers have looked to the heaps of small coal at the pit's mouth.

compass-box [1797] $1851 \mathrm{R}$. H. HORNE 438 With compass-box in hand.

cooling floor, room $1852 \mathrm{~W}$. M. THOMAS 112 On the cooling-floor, I find a man stitching hop-pockets. . . We mount a ladder to the cooling-room attached to ther oast-house.

corking-machine $1855 \mathrm{E}$. S. DIXON 364 The corking-machine is . a cruel mode of forcibly stopping a vessel's mouth.

corsetier [1932] 1853 G. A. SALA 406 Our shop-keepers are merchant tailors, chemisiers, artists in hair, purveyors, costumiers, corsetiers - anything but tailors, shirt-makers, hair-workers, grocers, or stay-makers.

counter-sinking [1888] $1852 \mathrm{H}$. MARTINEAU 109 The forming of the little cup in the middle . . is called counter-sinking.

cream-laid [1857] $1850 \mathrm{~W}$. H. WILLS 427 A colour belonging neither to blue-wove [1863] nor yellow-wove, nor to cream-laid.

curling-pin [1909] $1853 \mathrm{G}$. DODD 233 How to use the curling-pins, and the scissors, and the brushes.

current-chart $1853 \mathrm{~J}$. CAPPER 128 Current-charts and maps of the hills and valleys of Old Ocean.

cutting-tool ** 1853 G. DODD 543 The cutting-tools with which the wood is planed do not move along its surface; but the wood travels up to the tools.

daguerrotyper [1864] $1852 \mathrm{~W}$. M. THOMAS $27 \mathrm{My}$ neighbour, the daguerrotyper.

deckled [1906] $1850 \mathrm{~W}$. H. WILLS 427 The rough $*$ fringiness of three of its edges are called the 'deckeled' edges.

dipping-house [1893] $1850 \mathrm{C}$. KNIGHT 56 These . . bundles . . are daily brought on a truck to the dipping-house.

distance signal [1874] $1853 \mathrm{H}$. MORLEY 44 Nothing can thoughtlessly be shunted through .. while the train is running from the distance signal to the station.

donkey-engine [1858] 1852 J. HANNAY 139 A little two-horse engine, which they call the 'donkey-engine'.

double-threaded [1909] 1853 J. CAPPER 182 The screw-propellers now most commonly in use are what are termed double-threaded, of about one-sixteenth of a convolution.

drawing-machine 1881] 1853 G. DODD 501 A 'carding-machine [1831]' lays all the fibres parallel; a 'drawing-machine' groups them into slender ribbons; a 'roving machine' slightly twists them into a soft spongy cord.

dusting-brush [1907] 1854 G. DODD $494 \ldots$ the great variety of brushes with which society is favoured. Painting-brushes, dusting-brushes, . . distemper-brushes**, bannister-brushes, . . nail-brushes, . . hat-brushes, velvet-brushes, carpet-brooms, hearth-brooms, stair-brooms, birch-brooms, long-brooms, stable-brooms, whiskbrooms. 
egg-and-tongue ** $1853 \mathrm{G}$. A. SALA 378 Sepulchral beadings, and egg-and-tongue fillets like rows of coffin nails.

electro-process [c 1865] 1852 G. A. SALA 227 Like plates multiplied by the electro-process - like the printer's 'stereo' - like the reporter's 'manifold [1884]' - you will find duplicates, triplicates of these forlorn beings everywhere.

emery ** v. 1852 G. DODD 611 Many walking-sticks . . are sand-papered, or emeried, or rotten-stoned ${ }^{* *}$, and are further smoothed with fish-fin or fish-skin.

field-trial $* * 1854 \mathrm{~S}$. SIDNEY \& W. H. WILLS 116 In the field-trials at Lincoln there was nothing more exciting . than the .. competition between the *machine reapers.

fire-extinguishing [1876] 1854 G. DODD 43 One inventor shows .. his fire-extinguishing apparatus in all the elegance of modern furniture.

fishtail burner [1864] 1851 G. A. SALA 128 'Holliday's lamps', green paper shades, 'fishtail' burners.

flail-thrashing 1854 S. SIDNEY \& W. H. WILLS 116 Hand-hoeing, flail-thrashing . . are the rule.

fly-shuttle 1851 DICKENS 28 Nothing would induce him to use a simple improvement (the 'fly shuttle').

germ 3 [1871] $1853 \mathrm{H}$. MORLEY 408 A certain animalcule or a certain fungus coming into contact with the air passages may be the cause of the peculiar irritation [influenza], and its germs carried about by a person who has been among them may be communicated by him - through contact, or contagion - to his neighbours.

glue-maker [1885] 1853 G. DODD 464 The *leather-factors, the leather-dressers, the leather-dyers [1515], the parchment-makers, and the glue-makers, for which this district is so remarkable.

goods train [1885] 1854 DICKENS 291 The Goods trains come in, banging and whanging over the turning-plates.

hammer-pick ** 1853 G. MURRAY 458 Pickaxe, mattock, hammer-pick.

hop-drier [1875] 1852 W. M. THOMAS 112 The grower, by long experience (for nothing else will make a hop-drier), knows . that it is exactly the proper heat.

horse1f [1904] 1853 E. S. DIXON 564 The passage leading to the fifteen-horse steamengine.

horse-hoe 1855 S. SIDNEY 163 Drills and *manure distributors, and horse-hoes, a Crosskill's clod-crusher, and a heavy *stone-roller.

inking roller $1854 \mathrm{G}$. DODD 439 That peculiar mixture of glue and treacle whereof printers' inking-rollers are made.

ink man [1619] $1853 \mathrm{~J}$. LANG 96 The press-man lifted the form, and was carrying it with the assistance of an ink man, . . when he stumbled and fell.

kill $v$. 3h [1934] $1854 \mathrm{G}$. A. SALA 42 There is your fine-art amateur, who pokes about studios, and advises you to kill that light, and scumble that background, and glaze down that little finger.

knitting machine [1858] 1853 Adelaide PROCTOR 111 A knitting-machine . . turned out beautifully knitted grey stockings.

lacing-machine $1852 \mathrm{H}$. MARTINEAU 554 The man seated at the '* piano-machine,' playing on a sort of keys, from the coloured pattern stuck up before his eyes, is punching the Jacquard cards, which are then transferred . . to the lacing-machine, where they are strung together.

leather-embosser 1853 G. DODD 59 The leather-embossers have begun to sell the simple tools . requisite for the practice of this pretty art. 
light-boat, -room [1875] 1852 R. H. HORNE 23 A light-ship (we call them all lightboats [1858]) is a creature of peculiar construction. 1851374 The 'light-room' at the summit of the tower.

limp leather [1863] $1850 \mathrm{~F}$. K. HUNT 236 The books are oblong folios, with limp leather covers.

llama cloth [1871] 1852 H. MORLEY \& W. H. WILLS 382 All our combinations of Welsh flannel, Llama cloth, and Mackintosh are infinitely inferior to the coverings of the duck and the goose.

machine $v$. Printing [1878] 1853 G. A. SALA 255 A printer's boy, going with a truck full of 'forms' ready for 'machining' towards Boot Lane.

magnet-house [1900] $1850 \mathrm{~F}$. K. HUNT $223 \mathrm{Now}$, in the magnet-house, we see light and chemistry doing the tasks before performed by human labour.

manifold writer [1872] $1852 \mathrm{~W}$. M. THOMAS 257 Scribbling on tissue paper with a manifold writer.

mezzanine floor [1859] 1853 G. A. SALA 604 Somewhere underneath the 'grave-trap' in the mezzanine floor, or high in the tackled flies.

nail-cutting, -making $1851 \mathrm{H}$. MARTINEAU 138 Steam-engines and nail-cutting machines. - 139 There is nail-making going on at Montreal.

network (of a railway) [1869] $1850 \mathrm{~W}$. H. WILLS 482 The three kingdoms would be intersected by a net-work of railroad measuring twelve thousand miles.

nicking machine [1753] $1851 \mathrm{H}$. MARTINEAU 141 The next thing is to 'nick' the head [of the screws]. This . . used to be done by working the 'nicking' machine with treadles.

obturator 2c [1887] 1853 H. MORLEY \& W. H. WILLS 58 A black stopper (the obturator) was clapped over the glass in front.

oiler 1 [1818] 1853 E. S. DIXON 116 Take it [the colza harvest] to the oil-mill and hand it over to your own oiler.

oil-tank 1923] 1852 R. H. HORNE 23 We pass on to the oil-store. . A compact set of oiltanks and cisterns.

ovalo 1853 G. DODD 543 Whether the moulding be called an 'ogee' or an 'ovalo,' a 'bead' or a 'fillet', a 'hollow' or a 'bevel'.

paddle-box boat [1859] 1851 DICKENS 337 In the days of my grandfather, there yet existed an invention called Paddle-box Boats.

pastrami [1940] 1853 B. St. JOHN \& W. H. WILLS 374 The common articles of food [in Varna] are pastrum a that is to say, the meat of oxen or buffaloes salted and dried in the sun, or sutjoukia, sausages made of the same meat .

pencil-maker [1875] 1854 G. DODD 26 Aug. 45 Pencil-makers are looking about them somewhat anxiously.

Pinot [1912] 1854 E. S. DIXON 310 The first and highest in excellence is the Pineau, or Pinot, names guessed to be derived from $\pi \mathrm{iv} \omega$.

pipe-drain $v$. [1907], - drainage [1907] $1852 \mathrm{H}$. MORLEY $291 \mathrm{~A}$ hundred and fifty miles of pipe drain. . . Upwards of eighteen thousand houses have been pipedrained. . . The pipe drainage prives itself . . cheaper . . than the old system of drains and sewers of deposit.

plant-cell 1854 E. A. HART 485 The life of the Plant-cell is but a fact of the life of the entire material world.

plate-printed, -printing ** $1850 \mathrm{~J}$. KAVANAGH \& W. H. WILLS 428 The note is . plate-printed. -427 A row of plate-printing presses. 
pump-borer [1708] 1853 E. S. DIXON 367 In French, a pump-borer is likewise called a cuillère.

punching press [a 1884] 1852 G. DODD 590 Compressing the red-hot rivets in the ordinary punching press.

quartz-crusher ** $1855 \mathrm{H}$. MORLEY 91 The failure of his quartz-crusher.

quartz-crushing [1882] $1855 \mathrm{H}$. MORLEY 91 That gentleman commenced a quartzcrushing experiment. .. His . quartz-crushing machine.

quartz-mining [1872] $1854 \mathrm{H}$. MORLEY $287 \mathrm{He}$ believes in quartz mining. Thinks that the directors of a quartz mining company make a snug thing of it.

rise sb. ?I. 4d [1905] 1853 G. A. SALA 194 That stage where there are more sinks and rises, more drops, flats, borders, set pieces, wings and floats .. than [etc.]

rolling vbl sb. ${ }^{2}$ 3b [1937] Lithography 1852 G. A. SALA 180 The drawing is now carefully washed with rain-water, and is now ready for 'gumming in' and 'rolling up'.

sea-moth [1905] 1854 H. MORLEY 508 The common Sepiole . . covers the water-plants like a sea-moth.

sécateur [1881] $1855 \mathrm{E}$. S. DIXON 33 There is an instrument called a sécateur, a combination of pincers and scissors, and a great favourite with ignorant vine-dressers and lazy gardeners.

Sémillon [1875] 1855 E. S. DIXON 364 The St. Emilion, or Semillon, is a variety . . easily recognised by .. its high-shouldered [1837] bunches.

shingling hammer [1857] $1852 \mathrm{G}$. DODD $590 \mathrm{~A}$ few mighty thumps from a shingling hammer.

shoot $v$. 32c [1867] 1851 R. H. HORNE 374 A sailor anxiously 'shooting' the horizon with his night-glass.

sinker $s b .{ }^{1} 5 \mathrm{~b}$ [1882] $1852 \mathrm{R}$. H. HORNE $22 \mathrm{~A}$ buoy is kept in its place by a large chain .. fastened to a large flat iron slab, called a 'sinker'.

smoke-proof [1901] $1850 \mathrm{~W}$. H. WILLS 27 No part of the building is smoke-proof.

snap-lock [1913] 1854 G. A. SALA 437 Marvellous pocket-books, with .. snap-locks.

soft-ware 1850 R. H. HORNE 380 Two other departments [among rubbish-tip pickers], called the 'soft-ware' and the 'hard-ware', are very important. The former includes all vegetable and animal matters - everything that will decompose. . . Under this head, also, the dead cats are composed.

stall-feeding $1853 \mathrm{H}$. MORLEY 386 Stall-feeding began in England as a matter of necessity.

steering-wheel [1902] 1850 R. H. HORNE 605 The most important result of this first trial [of steam ploughing, in Oct. 1845] was the establishment of a new mechanical principle, viz. , "the transmission of power from a fixed point to a moving point, going in arbitrary directions at the will of one man at the steering wheel."

straw-shaker [1869] 1851 R. H. HORNE 358 The draining-plough, .. the harrow, the clod-crusher, the revolving sub-soiler [1852] . , the straw-shaker.

stream-pump 1855 J. CAPPER \& S. SIDNEY 448 What would half our coal mines be worth, worked on Indian principles, with stream-pumps, and with only cart-roads to market?

sugar-paper [1926] 1853 J. OXENFORD 353 The [doll's head] maker . . makes a mould, and in this mould he fashions impressions made of a kind of sugar-paper.

sun-shield [1974] 1852 G. DODD 201 In ancient Egypt . . these sun-shields [parasols] appear to have been used. 
swimming-plate[1940] 1854 H. MORLEY 508 A Porcelain crab, or Hairy Broadclaw . . is a crab with fringed swimming-plates

sympiesiometer $1854 \mathrm{H}$. MORLEY 461 Fancy an officer in a storm .. going to look at a sympesiometer in another place, that is fixed where it is subject to another temperature.

tarsia-work [1875] 1854 G. DODD 179 When the marquetrier. . produces wood pictures .. then his labour is frequently called tarsia-work.

throstle spinner [1862] 1853 J. LOWE 348 The card-room hands have their committee, and the throstle spinners, the tape machine sizers, and the power-loom overlookers theirs.

valve-line [1871], -motion $1851 \mathrm{R}$. H. HORNE 102 The valve-line is pulled! $1852 \mathrm{~J}$. HANNAY 139 The Orinoco is fitted with 'direct acting' engines; and a peculiarity, called the 'valve motion', enables one man to work both engines.

weather-cycle [1930] $1850 \mathrm{~F}$. K. H If the theory of weather-cycles holds good.

winnowing machine [1805] 1854 S. SIDNEY \& W. H. WILLS 116 The rude winnowing-machine dependent on a breezy day.

wire-brush $(b)$ [ $a$ 1935] 1854 G. DODD 218 Artificers .. fashion them [sc. wires] into . . button rings, . . card-teeth, wire-brushes, brush-wires, spiral springs, bonnet stiffeners.

yoke-collar [1906] $1852 \mathrm{~W}$. H. RUSSELL 192 Bullocks .. rearing aloft the great horned yoke-collar of wood. 